\title{
The Yield and Economical Efficiency by Application Methods of Liquid Pig Manure on Forage Crops
}

\author{
Chang-Hyun Ahn*, Woo-Sik Kim, Jee-Sung Park, and In Ahn ${ }^{1}$ \\ Korea Plant Environmental Research Station Ltd., Suwon, 481-813, Korea \\ ${ }^{1}$ Korea Eco-Friendly Agro-Materials Association, Seoul, 137-942, Korea
}

(Received: October 29 2013, Accepted: November 28 2013)

\begin{abstract}
This experiment was caried out to investigate the effect of liquid-pig-manure application method (Tr.1: surface appl. LPM 150\%, Tr.2: surface appl. LPM 50\% + LPM 50\%, Tr.3: chemical fertilizer, Tr.4: soil injection LPM 150\%, Tr.5: soil injection LPM 50\% + surface appl. 50\%, Tr.6: no fertilizer) and the economic efficiency of yield on forage crops cultivaion. In bartey cultivation experiment, Tr.5 was found to be best, showing the yield of $1,462 \mathrm{~kg} \mathrm{10a}^{-1}$, and followed by Tr.2(1,226 kg 10a $\left.\mathrm{a}^{-1}\right), \operatorname{Tr} .3\left(1,226 \mathrm{~kg} \mathrm{10a}{ }^{-1}\right), \operatorname{Tr} .4(1,225 \mathrm{~kg}$

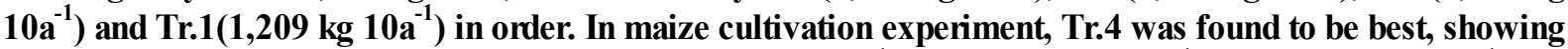
the yield of $2,142 \mathrm{~kg} / 10 \mathrm{a}$, and followed by Tr.1(2,125 kg 10a $\left.{ }^{-1}\right), \operatorname{Tr} .3\left(2,024 \mathrm{~kg} \mathrm{10a}^{-1}\right), \operatorname{Tr} .5\left(2,011 \mathrm{~kg} \mathrm{10a}^{-1}\right)$ and Tr.2(1,925 kg 10a $\left.{ }^{-1}\right)$ in order. The income was showing 1,274,000 1,591,000 Won $10 \mathrm{a}^{-1}$ in barley, whereas $766,000-794,000$ Won $10 \mathrm{a}^{-1}$ in maize. There was more economical efficiency in barley cultivation than maize cultivation. Rather than the LPM surface application, LPM soil injection was more effective.
\end{abstract}

Key words: Liquid pig manure, Yield, Barley, Maize, Economical efficiency

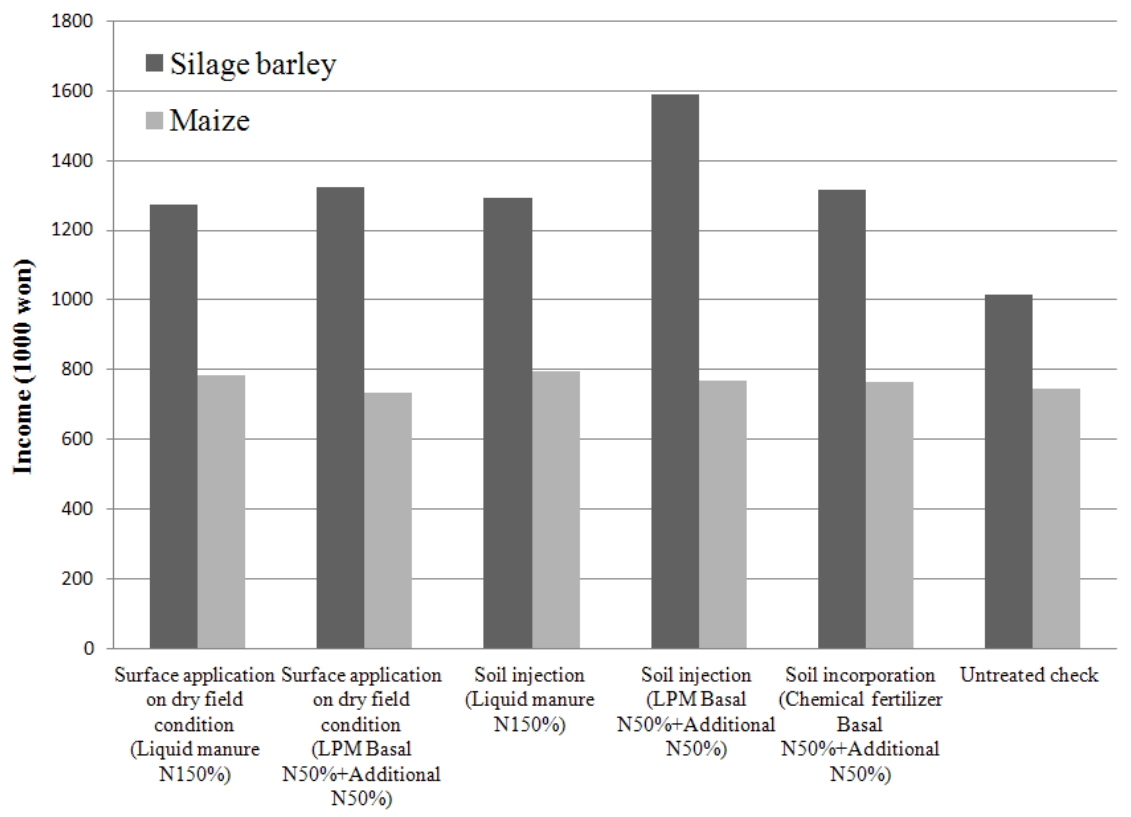

Economical efficiency of bartey and maize with different treatment methods of liquid pig manure. 


\section{Introduction}

우리나라 가축분뇨 발생량은 '08년 4,174만 톤에서 '09년 4,370만 톤, '10년 4,653만 톤, '11년 4,672만 톤으로 급격히 늘어나지는 않으나, 매년 조금씩 증가하고 있다. '11년 기준 $84 \%$ 가 자원화되어 환원되고, $2 \%$ 는 해양에 배출, $1 \%$ 는 정화 처리, $13 \%$ 는 위탁처리 후 방류되고 있으며 가축분뇨 해양배 출은 '05년을 정점으로 감소하는 추세이다(환경부 가축분뇨 통계, 2012). 가축분뇨 공공처리시설 설치 및 운영현황을 보 면 ' 12 년 전국 111 개소에서 하루 평균 13,486 톤의 양호한 처 리능력을 보유하고 있으나(환경부 가축분뇨통계, 2012), 관리 미흡시 오염원으로 작용하여 지표수와 지하수의 오염, 악취 발생 등 환경문제를 발생시키고(Sweeten, 1988), 부숙이 덜 된 퇴·액비는 비료로서 효과가 적고 악취민원 유발(NHERI, 2011) 등으로 경종농가에서 사용을 꺼리고 있는 실정이다.

가축분뇨에는 질소, 인산, 칼리를 비롯한 영양분들을 함 유하고 있어 작물생육을 촉진시키며, 토양의 물리·화학적 개선 효과가 있는 것으로 보고되어 있으므로(RDA, 2002), 수요 확대를 위해서는 충분히 부숙된 저농도 액비를 개발하 고 재배환경에 따른 시용방법을 보급할 필요가 있다. 가축 분뇨는 시용시기와 시용량에 따라 작물의 생육과 토양에 미 치는 영향이 다르고(Jeon et al., 2003; Kang et al., 2004; Lee et al., 2004; Lee et al., 2010; Park et al., 2001), 화 학비료에 비해 인력과 장비가 많이 소모된다.

이에 작물별 돈분액비의 시용방법에 따른 수량의 경제성

Table 1. Several methods of liquid pig manure application in filed.

\begin{tabular}{lc}
\hline \hline Basal application & Additional application \\
\hline $\begin{array}{l}\text { Surface application } \\
\text { (Liquid manure N150\%) }\end{array}$ & - \\
$\begin{array}{l}\text { Surface application } \\
\text { (Liquid manure N50\%) }\end{array}$ & $\begin{array}{c}\text { Surface application } \\
\text { (Liquid manure N50\%) }\end{array}$ \\
$\begin{array}{l}\text { Soil incorporation } \\
\text { (Chemical fertilizer N50\%) }\end{array}$ & Soil incorporation \\
Soil injection & - Chemical fertilizer N50\%) \\
(Liquid manure N150\%) & \\
Soil injection & Surface application \\
(Liquid manure N50\%) & (Liquid manure N50\%) \\
Untreated check & - \\
\hline
\end{tabular}

을 연구해 볼 필요가 있는 바, 본 연구에서는 사료작물 재배 시 돈분액비의 시용방법을 달리 하여 작물의 생육과 수량에 미치는 영향 및 경제적 효과를 고찰하였다.

\section{Materials and Methods}

사료작물 재배시 돈분액비 시용방법 실증 청보리 재배시험은 전라북도 김제시 죽산면에 위치한 벼-보리 이 모작 양토 시험포장에서 영양보리를 2010년 10월에 파종하 여 2011년 6월에 수확하였고, 옥수수 재배시험은 전라북도 김제시 금구면에 위치한 미사질양토 시험포장에서 사료용 옥수수를 2012년 5월에 파종, 8월에 수확하였다. 시험구별 처리내용은 Table 1과 같이 지중투입, 지상살포, 화학비료, 무시비를 조합하여 총 6 개 처리구를 두었으며, 시험구당 면 적은 $1,320 \mathrm{~m}^{2}$ 단구제로 돈분액비를 사료작물 재배에 이용 하는 다양한 시용방법을 모색하였다. 밑거름 시비는 화학비 료 표준 질소시비량 대비 돈분액비 $150 \%, 50 \%$ (이하 N150\%, $\mathrm{N} 50 \%$ )를 파종 7일 전 트랙터(존디어6610, 한국)에 탱크형 지상지중 겸용 살포기((주)주일산업, 한국)를 연결하여 지 상 및 지중투입하였다. 청보리 재배시험에서 웃거름 시비는 월동 후 2011년 3월 시험지역의 구제역 발생으로 인한 축산 부산물 반출금지 조치로 충남 예산 (주)을그린에서 돈분액 비를 공급받아 웃거름 시비구에 지상살포하였고, 옥수수 재 배시험에서는 5 6엽기에 지상살포하였다. 시험에서 사용한 돈분액비는 전북 김제시 용지면 용암리 비육돈 농장에서 약 6 개월간 계단식 발효조에서 상등액을 이동시키면서 부숙시 킨 것을 사용하였고, 액비의 화학성분은 비료의 품질검사방 법 $\mathrm{RDA}, 2006)$ 으로 분석하였다. 살포된 돈분액비의 질소량 은 2010년 0.22\%, 2012년 0.17\% 로 Table 2와 같이 질소 이 외에도 인산 및 칼리를 다량 함유하고 있었고, 중금속 함량 은 비료공정규격(농촌진흥청고시 제2009-29호, 농촌진흥 청고시 제2012-34호)의 규정보다 횔씬 낮은 값을 보였다. 각 시용방법은 시용기기와 액비 시용시간 및 시용방법에 따 른 문제점을 조사하였고, 현행 규정(비료관리법 비료 공정 규격 설정 및 지정 [별표2])상 주거지 $200 \mathrm{~m}$ 이내는 액비살 포금지 구역이나 6개월 이상 부숙된 저농도 액비를 주거지 $200 \mathrm{~m}$ 이내 시용에 따른 민원 발생 소지를 검증하기 위해 암모니아 가스 발생량을 콤백(CoMMe-100)으로 측정하였 다. 시용방법에 따라 균일도가 떨어지거나 액비가 과다 시 용지점의 토양 이화학성을 조사하였고, 시험에 사용된 토양

Table 2. The chemical and heavy metal properties of used liquid pig manure.

\begin{tabular}{|c|c|c|c|c|c|c|c|c|c|c|}
\hline Year & T-N & $\mathrm{P}_{2} \mathrm{O}_{5}$ & $\mathrm{~K}_{2} \mathrm{O}$ & $\mathrm{Na}_{2} \mathrm{O}$ & $\mathrm{Cu}$ & $\mathrm{Pb}$ & $\mathrm{Zn}$ & $\mathrm{Cr}$ & $\mathrm{Ni}$ & $\mathrm{pH}$ \\
\hline & \multicolumn{4}{|c|}{---o- } & ------- & - & $\mathrm{mg} \mathrm{k}$ & ------ & ----- & $1: 5$ \\
\hline 2010 & 0.22 & 0.03 & 0.15 & 0.17 & 4.79 & 3.2 & 15.2 & 2.57 & 2.79 & 8.2 \\
\hline 2012 & 0.17 & 0.01 & 0.13 & 0.1 & 6.69 & 3.75 & 7.81 & 5.86 & 4.14 & 8.3 \\
\hline
\end{tabular}


의 이화학성은 일반화학분석법(NIAST, 2000)으로 분석하였 다. $\mathrm{pH}$ (ATI ORION EA940) 및 EC(Themo ORION 3STAR)는 토양과 증류수의 비율을 $1: 5$ 로 하여 측정하였으며, 유기물 은 Tyurin법으로, 유효인산은 Lancaster법을 이용한 비색 법(Perkin Elmer Lamda25)으로 하였다. 처리별 보리 생육 조사를 위하여 출현율, 초장, 수량, 수량지수를 시비방법별 3 개 지점에서 시료를 채취하여 조사하였고, 옥수수 생육조 사는 간장, 이삭길이, 건물중, 수량지수를 조사하였다.

\section{돈분액비 사료작물별 시용방법에 따른 경제성 분석} 돈분액비 시비법에 따른 경제적 효과를 분석하기 위해 산출 근거로 먼저 액비 투입비는 장비 및 살포비용을 포함 톤당 12 천원, 작물표준시비량기준 액비량 $10 \mathrm{a}$ 당 청보리 5.12 톤, 옥수수 6.88 톤을 살포기준으로 삼았다. 화학비료 투입비는 질소-인산-칼리 복합비료 $20 \mathrm{~kg}$ 1포당 13 천원을 $10 \mathrm{a}$ 당 3 포 기준으로 사용하고, 살포시 인건비는 남자 1 인이 1 일 90 천 원으로 $30 \mathrm{a}$ 를 살포하는 것을 기준으로 하였다. 조수익 산출 은 옥수수는 2012년 전북지역 사일리지 옥수수 수매가 기준 413 원 $\mathrm{kg}^{-1}$, 청보리 가격은 2011년 전북지역 영양보리 수매 가인 1,130 원 $\mathrm{kg}^{-1}$ 을 기준으로 하여 포장시험에서 조사된 생 산량을 곱하여 조수익을 산출하였다. 경영비는 종묘비, 비 료비, 농약비, 재료비, 농구비, 고용노력비, 위탁영농비, 토 지 및 자본용역비로 구분할 수 있으나, 청보리 및 옥수수의 사료작물효과를 보는 단기간의 시험이므로 크게 종자대, 액 비살포비, 화학비료대 인건비만으로 단순화하여 산출하였 다. 종자대는 옥수수는 $\mathrm{kg}$ 당 413 원으로 $10 \mathrm{a}$ 당 $2.5 \mathrm{~kg}$ 를 파 종하는 것을 기준으로 하였고, 청보리 종자대는 정부 및 지 자체에서 무상지원하고 있으므로 산정치 않았으며 액비살 포비는 장비 및 살포 비용 $10 \mathrm{a}$ 당 12 천원, 화학비료 살포 인 건비는 $10 \mathrm{a}$ 당 30 천원을 기준으로 하였다. 경제적 효과는

Table 3. Descriptions of several application methods to treated liquid pig manure.

\begin{tabular}{lcccc}
\hline \hline \multirow{2}{*}{ Treatment } & \multicolumn{4}{c}{ Applicated Applicated Applicated } \\
& coverage & time & amount & Average \\
\hline & $\mathrm{m}^{2}$ & sec. & ton & $\begin{array}{c}\text { sec. } \\
\text { ton }\end{array}$ \\
Surface application & 2,640 & 1,237 & 13.6 & 91 \\
Soil injection & 2,640 & 1,410 & 13.6 & 104 \\
\hline
\end{tabular}

전체 조수익에서 경영비를 차감하여 산출하였다.

\section{Results and Discussion}

청보리 재배시 돈분액비 시용 실증 돈분액비는 수 분함량이 많고 경작지에 직접 살포함으로써 퇴비에 비해 간 편하여 사료작물 목초지에 많이 사용되고 있으나, 많은 양 을 살포하고 대형장비가 사용되기 때문에 경지정리가 잘되 어 있고 면적이 넓은 경작지에 사용하는 것이 효율적이다. 본 연구에서 사용한 돈분액비 시용시간 및 시용량은 Table 3 과 같이 지상살포와 지중투입이 각각 $91 \mathrm{sec} . \mathrm{ton}^{-1}$ 과 104 sec. $\operatorname{ton}^{-1}$ 로 비슷한 처리시간을 보였으나, 지상살포가 약 간 빠른 처리시간을 보였다. 각 시용방법은 5 톤 씩 살포장 비의 액비탱크에 저장하여 살포하였으며, 5 톤당 5 분의 공급 시간이 발생하였다. 살포시 큰 문제점은 없었으나, 액비 내 고형물로 인한 노즐 막힘 현상이 살포 후반 발생하였다.

각 시용방법의 장단점을 종합한 결과, 돈분액비의 지중 투입 시 탱크형 장비의 경우 85 마력 이상의 높은 마력의 트 랙터가 필요하기 때문에 지형이 불균일한 곳에서는 호스를 연장하여 독립식 장비를 사용하는 것이 효과적이고, 지상살 포에 비해 경운작업을 생략할 수 있기에 작업을 한단계 감 소시킬 수 있다.

Table 4는 액비를 시용한 후 암모니아 가스의 발생 변화 를 표시하였다. 액비를 시용한 직후 지상살포는 $45 \mathrm{mg} \mathrm{L}^{-1}$, 지중투입이 $10 \mathrm{mg} \mathrm{L}^{-1}$ 로 지중투입의 경우에 약 $25 \%$ 수준으 로 암모니아 가스 발생이 적었다. 살포 24시간 후 지중투입 구는 암모니아 가스 발생이 거의 사라졌으며, 72 시간 후에 는 전혀 발생하지 않았다. 시용방법에 따라 암모니아 가스 발생량이 차이가 나기 때문에 민가가 인접한 재배지에서는 지중투입이 액비시용에 따른 거부감을 줄일 수 있을 것으로 사료된다.

돈분액비가 보리 생육에 미치는 효과를 조사하기 위해 수확기에 식물체를 채취하여 조사한 결과, Table 5에서 보 는 바와 같이 $10 \mathrm{a}$ 당 수확량은 무시비구에서 $898 \mathrm{~kg}$, 관행인 화학비료 시비구는 $1,226 \mathrm{~kg}$ 이었고, 가장 많은 수확량을 보 인 지중투입(밑거름 + 웃거름)구는 $1,462 \mathrm{~kg}$ 의 수확량을 나 타내어 무비구보다 $46 \%$ 증수되었다. 화학비료 시비구와 비 교하여도 $19 \%$ 증수효과를 나타내었다. 본 시험에서는 돈분 액비를 관행적으로 전량 밑거름하지 않고 밑거름과 웃거름

Table 4. Change of $\mathrm{NH}_{3}$ gas volatilzation in soil at several application methods to treated liquid pig manure.

\begin{tabular}{|c|c|c|c|c|c|c|c|}
\hline Treatment & 0 hour & 2 hour & 5 hour & 24 hour & 48 hour & 72 hour & 120 hour \\
\hline Surface application & 45 & 30 & 5 & 3 & 3 & 3 & $\mathrm{~N}^{\dagger}$ \\
\hline Soil injection & 10 & 7 & 1.5 & 0.5 & 0.5 & $\mathrm{~N}$ & $\mathrm{~N}$ \\
\hline
\end{tabular}

${ }^{\dagger} \mathrm{N}$ : Not detected 
으로 나누어 시비하였는데 웃거름을 시용하지 않은 돈분액 비 $\mathrm{N} 150 \%$ 시비구에서는 부분적으로 봄철 한발에 의한 생육 저하가 관찰된 반면 웃거름을 시용한 처리구에서는 한발 피 해가 없었다. 작물 재배 시 품종이나 시비한 비종에 따라서 도 수량에 차이가 있겠지만, 시비량이나 시비법에 의한 차 이도 큰 것으로 보고되어 있고(Kim et al., 1993; Park et al., 2002), 본 시험에서와 같이 시용방법에 따라 각 처리구 별로 수량의 차이를 보여 돈분액비 이용 작물 재배시 시용 방법에 따른 차이도 클 것으로 판단된다.

사료용 옥수수 재배시 돈분액비 시용 실증 본 연구 에서 사용한 돈분액비 시용방법에 따른 시용시간 및 시용량 은 Table 6과 같이 지상살포와 지중투입이 각각 $72 \mathrm{sec}$. $\operatorname{ton}^{-1}$ 과 $114 \mathrm{sec} . \mathrm{ton}^{-1}$ 의 처리시간을 보였으며, 지상살포가 지중투입에 비해 빠른 처리시간을 보였다. 지중투입에서는 전 작물 라이그라스의 예취가 완전히 이루어지지 않은 부분 에서 뿌리에 의해 투입기가 액비 유입기에 걸림현상이 발생 하였다.

Table 7은 액비를 시용한 후 논토양의 이화학적 변화를 표시하였다. $\mathrm{pH}$ 는 액비를 시용하기 전에는 5.8 6.2 였으 나, 액비시용 후에는 모든 처리구가 6.1 6.6 으로 나타났 다. 암모늄태 질소 및 질산태 질소는 지중 $\mathrm{N} 50 \%$ + 지상 $\mathrm{N} 50 \%$ 시비구에서 가장 높게 나타났다. 이와 같은 결과는 토양에서 배수조건과 기계작업에 따른 양분이동, 액비시용
에 따른 무기양분의 용탈, 옥수수의 양분 흡수량 등에 의해 암모늄태 질소와 질산태 질소의 휘산(Frost et al, 1990; Pain et al., 1990), 용탈 및 유실(Ishima et al., 1974; Xie and Mackenzie, 1986)되는 양이 다르기 때문인 것으로 추 정된다.

수확기에 식물체를 채취하여 조사한 결과, Table 8과 같 이 가장 적은 수확량을 보인 무시비구에서 간장, 이삭길이,

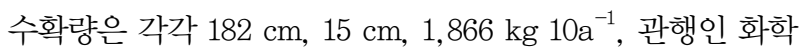
비료 시비구는 각각 $197 \mathrm{~cm}, 18 \mathrm{~cm}, 2,024 \mathrm{~kg} \mathrm{10a}^{-1}$ 이었고, 지중투입 N150\% 시비구는 각각 $221 \mathrm{~cm}, 21 \mathrm{~cm}, 2,142 \mathrm{~kg}$ $10 \mathrm{a}^{-1}$ 의 결과를 보여 수확량에서 무시비구보다 $15 \%$ 증수되 었으며 화학비료 시비구와는 수량차이가 없었다.

본 시험기간 동안 여름철 강수량 부족으로 무시비구에서 는 고사가 발생하였으나, 돈분액비를 처리한 시험구에서는 피해가 적고 옥수수의 수량도 화학비료 시비구에 비교하여 증수되었다. 앞서 청보리 재배시험과 같이 품종이나 시비한 비종, 시비량, 시비법 등에 의한 차이가 나타나므로 돈분액 비를 사용하여 작물 재배시 돈분액비 내 성분과 재배환경을 고려하여 가장 적합한 시용방법을 선택하는 것이 수량증진 에 크게 기여할 것으로 판단된다.

사료작물 돈분액비 시용 실증 경제성 분석 본 연구 에서 사용한 각 시용방법별 돈분액비의 경제적 효과를 비교 분석한 결과는 Table 9 와 같다.

Table 5. Yield and yield components of barley with different treatment methods of liquid pig manure.

\begin{tabular}{|c|c|c|c|c|c|}
\hline \multicolumn{2}{|l|}{ Treatment } & \multirow{2}{*}{ Emergence rate } & \multirow{2}{*}{ Plant length } & \multirow{2}{*}{ Yield } & \multirow{2}{*}{ Quantum index } \\
\hline Basal & Additional & & & & \\
\hline & & $\%$ & $\mathrm{~cm}$ & $\operatorname{kg} 10 \mathrm{a}^{-1}$ & $\%$ \\
\hline $\begin{array}{l}\text { Surface application } \\
\text { (Liquid manure N150\%) }\end{array}$ & - & $88.0 \mathrm{n} . \mathrm{s}^{\dagger}$ & 75.1 n.s & $1,209 b$ & 101 \\
\hline $\begin{array}{l}\text { Surface application } \\
\text { (Liquid manure N50\%) }\end{array}$ & $\begin{array}{l}\text { Surface application } \\
\text { (Liquid manure N50\%) }\end{array}$ & 89.0 n.s & 73.6 n.s & $1,226 \mathrm{~b}$ & 100 \\
\hline $\begin{array}{l}\text { Soil incorporation } \\
\text { (Chemical fertilizer N50\%) }\end{array}$ & $\begin{array}{l}\text { Soil incorporation } \\
\text { (Chemical fertilizer } \mathrm{N} 50 \% \text { ) }\end{array}$ & 90.0 n.s & 75.5 n.s & $1,226 \mathrm{~b}$ & 100 \\
\hline $\begin{array}{l}\text { Soil injection } \\
\text { (Liquid manure N150\%) }\end{array}$ & - & 89.0 n.s & 76.5 n.s & $1,225 b$ & 100 \\
\hline $\begin{array}{l}\text { Soil injection } \\
\text { (Liquid manure N50\%) }\end{array}$ & $\begin{array}{l}\text { Surface application } \\
\text { (Liquid manure N50\%) }\end{array}$ & 89.0 n.s & 75.0 n.s & $1,462 \mathrm{a}$ & 119 \\
\hline Untreated check & - & 90.0 n.s & 73.6 n.s & $898 \mathrm{c}$ & 73 \\
\hline
\end{tabular}

${ }^{\dagger}$ Means by the same letter within a column are not significantly different at 0.05 probability level according to DMRT.

Table 6. Descriptions of several application methods to treated liquid pig manure.

\begin{tabular}{lcccc}
\hline \hline Treatment & Applicated coverage & Applicated time & Applicated amount & Average \\
\hline & $\mathrm{m}^{2}$ & sec. & ton & ${\text { sec. } \text { ton }^{-1}}$ \\
Surface application & 2,640 & 1,972 & 17.3 & 114 \\
Soil injection & 2,640 & 1,246 & 17.3 & 72 \\
\hline
\end{tabular}


Table 7. Chemical properties of soil with different treatment methods of liquid pig manure.

\begin{tabular}{|c|c|c|c|c|c|c|}
\hline \multicolumn{2}{|l|}{ Treatment } & \multirow{2}{*}{$\mathrm{pH}$} & \multirow{2}{*}{ O.M } & \multirow{2}{*}{ Av. $\mathrm{P}_{2} \mathrm{O}_{5}$} & \multirow{2}{*}{$\mathrm{NH}_{4}$} & \multirow{2}{*}{$\mathrm{NO}_{3}$} \\
\hline Basal & Additional & & & & & \\
\hline & & $1: 5$ & $\mathrm{~g} \mathrm{~kg}^{-1}$ & $m g \mathrm{~kg}^{-1}$ & $\mathrm{mg} \mathrm{kg}^{-1}$ & $\mathrm{mg} \mathrm{kg}^{-1}$ \\
\hline $\begin{array}{l}\text { Surface application } \\
\text { (Liquid manure N150\%) }\end{array}$ & - & $6.1 \mathrm{n} . \mathrm{s}^{\dagger}$ & $7.39 \mathrm{a}$ & $87.66 \mathrm{~b}$ & $6.0 \mathrm{a}$ & $15.0 \mathrm{a}$ \\
\hline $\begin{array}{l}\text { Surface application } \\
\text { (Liquid manure N50\%) }\end{array}$ & $\begin{array}{l}\text { Surface application } \\
\text { (Liquid manure N50\%) }\end{array}$ & $6.38 \mathrm{n} . \mathrm{s}$ & $4.93 b$ & $57.48 \mathrm{~cd}$ & $2.0 \mathrm{~b}$ & $10.0 \mathrm{~b}$ \\
\hline $\begin{array}{l}\text { Soil incorporation } \\
\text { (Chemical fertilizer N50\%) }\end{array}$ & $\begin{array}{l}\text { Soil incorporation } \\
\text { (Chemical fertilizer } \mathrm{N} 50 \% \text { ) }\end{array}$ & $6.08 \mathrm{n} . \mathrm{s}$ & $5.14 b$ & $52.56 \mathrm{~d}$ & $1.0 \mathrm{~b}$ & $10.0 \mathrm{~b}$ \\
\hline $\begin{array}{l}\text { Soil injection } \\
\text { (Liquid manure N150\%) }\end{array}$ & - & 6.12 n.s & $5.79 b$ & $78.88 b c$ & $2.0 \mathrm{~b}$ & $10.0 \mathrm{~b}$ \\
\hline $\begin{array}{l}\text { Soil injection } \\
\text { (Liquid manure N50\%) }\end{array}$ & $\begin{array}{l}\text { Surface application } \\
\text { (Liquid manure N50\%) }\end{array}$ & $6.56 \mathrm{n} . \mathrm{s}$ & $6.27 \mathrm{ab}$ & $113.29 a$ & $10.0 \mathrm{a}$ & $20.0 \mathrm{a}$ \\
\hline Untreated check & - & 6.24 n.s & $5.31 \mathrm{~b}$ & $42.64 d$ & $1.0 \mathrm{~b}$ & - \\
\hline
\end{tabular}

${ }^{\dagger}$ Means by the same letter within a column are not significantly different at 0.05 probability level according to DMRT.

Table 8. Yield and yield components of maize with different treatment methods of liquid pig manure.

\begin{tabular}{|c|c|c|c|c|c|}
\hline \multicolumn{2}{|l|}{ Treatment } & \multirow{2}{*}{ Culm length } & \multirow{2}{*}{ Ear length } & \multirow{2}{*}{ Yield } & \multirow{2}{*}{ Quantum index } \\
\hline Basal & Additional & & & & \\
\hline & & $\mathrm{cm}$ & $\mathrm{cm}$ & $\mathrm{kg} 10 \mathrm{a}^{-1}$ & $\%$ \\
\hline $\begin{array}{l}\text { Surface application } \\
\text { (Liquid manure N150\%) }\end{array}$ & - & $212 \mathrm{a}^{\dagger}$ & $21 \mathrm{a}$ & $2,125 \mathrm{ab}$ & 105 \\
\hline $\begin{array}{l}\text { Surface application } \\
\text { (Liquid manure N50\%) }\end{array}$ & $\begin{array}{l}\text { Surface application } \\
\text { (Liquid manure N50\%) }\end{array}$ & $209 a$ & $18 \mathrm{a}$ & $1,925 \mathrm{c}$ & 95 \\
\hline $\begin{array}{l}\text { Soil incorporation } \\
\text { (Chemical fertilizer N50\%) }\end{array}$ & $\begin{array}{l}\text { Soil incorporation } \\
\text { (Chemical fertilizer N50\%) }\end{array}$ & $197 \mathrm{a}$ & $18 \mathrm{a}$ & $2,024 a b c$ & 100 \\
\hline $\begin{array}{l}\text { Soil injection } \\
\text { (Liquid manure N150\%) }\end{array}$ & - & $221 \mathrm{a}$ & $21 \mathrm{a}$ & $2,142 \mathrm{a}$ & 106 \\
\hline $\begin{array}{l}\text { Soil injection } \\
\text { (Liquid manure N50\%) }\end{array}$ & $\begin{array}{l}\text { Surface application } \\
\text { (Liquid manure N50\%) }\end{array}$ & $211 \mathrm{a}$ & $19 \mathrm{a}$ & $2,011 b c$ & 99 \\
\hline Untreated check & - & $182 b$ & $15 b$ & $1,866 \mathrm{~d}$ & 89 \\
\hline
\end{tabular}

${ }^{\dagger}$ Means by the same letter within a column are not significantly different at 0.05 probability level according to DMRT.

$10 \mathrm{a}$ 당 청보리 생산량은 무시비구 $898 \mathrm{~kg}$ 대비 지상살포 액비밑거름 N $150 \%$ 시비구가 $1,209 \mathrm{~kg}$, 지상살포 밑거름 $\mathrm{N} 50 \%$ + 웃거름 N50\% 시비구가 $1,226 \mathrm{~kg}$, 지중살포 밑거름 $\mathrm{N} 150 \%$ 시비구가 $1,225 \mathrm{~kg}$, 지중살포 밑거름 $\mathrm{N} 50 \%$ + 웃거 름 $\mathrm{N} 50 \%$ 시비구가 $1,462 \mathrm{~kg}$ 로서 뚜렷한 차이를 보였다. 화 학비료 시비구에 비해 지상살포 밑거름 $\mathrm{N} 50 \%$ 시비구가 $97 \%$, 밑거름 $\mathrm{N} 50 \%$ + 웃거름 $\mathrm{N} 50 \%$ 시비구는 $101 \%$, 지중살 포 밑거름 $\mathrm{N} 150 \%$ 시비구는 $98 \%$, 지중살포 밑거름 $\mathrm{N} 50 \%+$ 거름 $\mathrm{N} 50 \%$ 시비구는 $121 \%$ 로서 화학비료 대체효과 또한 가 장 우수하였다.

$10 \mathrm{a}$ 당 옥수수 생산량은 무시비구 $1,806 \mathrm{~kg}$, 화학비료 시 비구 $1,925 \mathrm{~kg}$, 가장 높은 수확량을 보인 지중투입(밑거름 + 웃거름) 시비구가 $2,142 \mathrm{~kg}$ 였으며, 조수입은 화학비료 시 비구 대비 지상살포 밑거름 N50\% + 웃거름 N50\% 시비구는
$96 \%$, 지상살포 액비밑거름 N 150\% 시비구는 $103 \%$ 의 효과 를 나타냈으며, 지중살포 밑거름 N50\% + 웃거름 N50\% 시 비구는 $100 \%$, 지중살포 밑거름 N50\% 시비구는 $104 \%$ 로서 가장 우수한 효과를 나타냈다. 옥수수 재배시 화학비료 시 비구에 대비 돈분액비 시비구가 96 104\%의 경제성를 보여 청보리에 비해서는 미흡한 결과를 보였다.

본 시험에서 돈분액비 시용에 따른 경제성을 살펴보면 $10 \mathrm{a}$ 당 조수입은 옥수수가 766 794 천원인 것에 비해 청보 리는 1,274 1,591 천원으로 나타나 옥수수보다는 청보리가 횔씬 더 경제성이 있었으며, 돈분액비의 지상살포보다 지중 투입이 더 효과적임을 알 수 있었다. 본 시험결과 옥수수, 청보리 등 사료작물 재배시 화학비료를 대체하여 돈분액비 를 사용하여도 충분히 경제성이 있을 것으로 판단된다. 
Table 9. Economical effeciencyof barley and maize with different treatment methods of liquid pig manure.

\begin{tabular}{|c|c|c|c|c|c|c|c|c|}
\hline \multirow{2}{*}{ Crop } & \multicolumn{2}{|c|}{ Treatment } & \multirow{2}{*}{ Yield } & \multirow{2}{*}{ Price } & \multirow{2}{*}{ Gross profit } & \multirow{2}{*}{ Managing cost } & \multirow{2}{*}{ Income } & \multirow{2}{*}{ Index $^{\dagger}$} \\
\hline & Basal & Additional & & & & & & \\
\hline & & & $\mathrm{kg} 10 \mathrm{a}^{-1}$ & won $\mathrm{kg}^{-1}$ & 1,000won & 1,000won & 1,000won & $\%$ \\
\hline \multirow{6}{*}{ Barley } & $\begin{array}{c}\text { Surface application } \\
\text { (Liquid manure N150\%) }\end{array}$ & - & 1,209 & 1,130 & 1,366 & 92 & 1,274 & 97 \\
\hline & $\begin{array}{c}\text { Surface application } \\
\text { (Liquid manure N50\%) }\end{array}$ & $\begin{array}{c}\text { Surface application } \\
\text { (Liquid manure N50\%) }\end{array}$ & 1,226 & 1,130 & 1,385 & 61 & 1,324 & 101 \\
\hline & $\begin{array}{c}\text { Soil incorporation } \\
\text { (Chemical fertilizer N50\%) }\end{array}$ & $\begin{array}{c}\text { Soil incorporation } \\
\text { (Chemical fertilizer N50\%) }\end{array}$ & 1,226 & 1,130 & 1,385 & 69 & 1,316 & 100 \\
\hline & $\begin{array}{c}\text { Soil injection } \\
\text { (Liquid manure N150\%) }\end{array}$ & - & 1,225 & 1,130 & 1,384 & 92 & 1,292 & 98 \\
\hline & $\begin{array}{c}\text { Soil injection } \\
\text { (Liquid manure N50\%) }\end{array}$ & $\begin{array}{c}\text { Surface application } \\
\text { (Liquid manure N50\%) }\end{array}$ & 1,462 & 1,130 & 1,652 & 61 & 1,591 & 121 \\
\hline & Untreated check & - & 898 & 1,130 & 1,015 & - & 1,015 & 77 \\
\hline \multirow{6}{*}{ Maize } & $\begin{array}{c}\text { Surface application } \\
\text { (Liquid manure N150\%) }\end{array}$ & - & 2,125 & 413 & 878 & 93 & 785 & 103 \\
\hline & $\begin{array}{c}\text { Surface application } \\
\text { (Liquid manure N50\%) }\end{array}$ & $\begin{array}{c}\text { Surface application } \\
\text { (Liquid manure N50\%) }\end{array}$ & 1,925 & 413 & 795 & 62 & 733 & 96 \\
\hline & $\begin{array}{c}\text { Soil incorporation } \\
\text { (Chemical fertilizer N50\%) }\end{array}$ & $\begin{array}{c}\text { Soil incorporation } \\
\text { (Chemical fertilizer N50\%) }\end{array}$ & 2,024 & 413 & 836 & 70 & 766 & 100 \\
\hline & $\begin{array}{c}\text { Soil injection } \\
\text { (Liquid manure N150\%) }\end{array}$ & - & 2,142 & 413 & 885 & 94 & 794 & 104 \\
\hline & $\begin{array}{c}\text { Soil injection } \\
\text { (Liquid manure N50\%) }\end{array}$ & $\begin{array}{c}\text { Surface application } \\
\text { (Liquid manure N50\%) }\end{array}$ & 2,011 & 413 & 831 & 62 & 769 & 100 \\
\hline & Untreated check & - & 1,866 & 413 & 746 & - & 746 & 97 \\
\hline
\end{tabular}

${ }^{\dagger}$ Compared to the chemical fertilizer income.

\section{Conclusions}

돈분액비 시용방법이 사료작물 재배시 수량에 미치는 영 향과 경제성을 비교하고자 청보리와 옥수수를 각각의 시용 방법에 따라 재배 후 수량 및 경제성을 조사하였다. 돈분액 비를 작물 표준시비량에 준하여 지상살포 및 지중투입 시용 방법으로 밑거름과 웃거름을 나누어 시비하여 사료작물을 재배한 결과, 청보리는 $10 \mathrm{a}$ 당 생산량이 무비구 $898 \mathrm{~kg}$, 화 학비료 시비구 $1,226 \mathrm{~kg}$, 지중투입(밑거름 + 웃거름) 시비 구가 $1,462 \mathrm{~kg}$ 로 뚜렷한 차이를 보였고, 이에 따라 경제성 도 무시비구에 비해 $125 \sim 157 \%$, 화학비료 시비구 대비 101 121\%로서 우수한 효과를 나타냈으며, 옥수수 10a당 생 산량은 무비구 $1,806 \mathrm{~kg}$, 화학비료 시비구 $2,024 \mathrm{~kg}$, 지중 투입 2,142 kg로 화학비료 대비 경제성에 큰 차이가 나타나 지 않았다. 돈분액비 시용효과는 $10 \mathrm{a}$ 당 경제성은 옥수수가 766 794 천원인 것에 비해 청보리는 1,274 1,591 천원으로 서 옥수수보다는 청보리가 더 경제성이 있었으며, 지상살포 보다는 지중투입이 더 효과적이었다.

\section{References}

Frost, J.P., R.J. Stevens, R.J. Laughlin. 1990. Effects of separation and acidification of cattle slurry on ammonia volatilisation and on the efficiency of slurry nitrogen for herbage production. J. of agri. sci., Cambrige 115:49-56.

Ishima, T., H. Taira, H. Taira K. Mikoshiba. 1974. Effects of nitrogenous fertilizer and protein content in milled rice on organoleptic quality of cooked rice. Rep. Nat. Food Res. Inst. 29:9-15.

Jeon, W.T., H.M. Park, C.Y. Park, K.D. Park, Y.S. Cho, E.S. Yun, and U.G. Kang. 2003. Effect of liquid pig manure application on rice growth and environment of paddy soil. Korean J. Soc. Soil Sci. Fert. 36:333-343.

Kang, B.G., H.J. Kim, G.J. Lee, and S.G. Park. 2004. Determination of the optimum application rate of pig slurry for red pepper cultivation. Korean J. Soil Sci. Fert. 37:388-395.

Kim, J.K., M.H. Lee, and Y.H. Kim. 1993. Lodging pattern of rice plant in broadcast-seeded and hand transplanted cultivation. Korean J. Crop Sci. 38:219-227.

Lee, J.T., C.J. Lee, and H.D. Kim. 2004. Utilization of liquid pig manure as a substitute for chemical fertilizer in double 
cropping system of rice followed by onion. Korean J. Soil Sci. Fert. 37:149-155.

Lee, S.T., D.C. Seo, E.S. Kim, W.D. Song, W.G Lee, J.S. Heo, and Y.H. Lee. 2010. Effect of Continual Application of Liquid Pig Manure on Malting Barley Growth and Soil Environment in Double Cropping System of Rice-Malting Barley. Korean J. Soc. Soil Sci. Fert. 43:341-348.

NIAST. 2000. Methods of soil and plant analysis, National Institute of Agricultural Science and Technology, RDA, Suwon, Korea.

Pain, B.F., R.B. Thompson, Y.J. Rees J.H. Skinner. 1990. Reducing gaseous losses of nitrogen from cattle slurry applied to grassland by the use of additives. J. of Science of Food and
Agri, 50:141-153.

Park, B.K., J.S. Lee, N.J. Cho, and K.Y. Jung. 2001. Effect of liquid pig manure on growth of rice and infiltration water quality. Korean J. Soc. Soil Sci. Fert. 34:153-157.

Park, J.S., W.W. Lee, Y.C. Ju, and Y.H. Kim. 2002. Field lodging degree of rice varieties according to nitrogen application rate. Korean J. Crop Sci. 47:226-235.

Sweeten, J.M. 1988. Composting manure sludge. In National poultry waste management symp., Columbus, $\mathrm{OH}$. Dep. of Poultry Sci., Ohio State Univ., Columbus. p.38-44.

Xie, R., A.F. Mackenzie. 1986. Urea and manure effects on soil nitrogen and corn dry matter yields. Soil Sci Soc. Am. J. 50:1504-1508. 